\title{
Oncogenic features of the bone morphogenic protein 7 (BMP7) in pheochromocytoma
}

\author{
Ines Leinhäuser ${ }^{1,2}$, Andrea Richter ${ }^{1}$, Misu Lee ${ }^{1}$, Ines Höfig ${ }^{2}$, Nataša Anastasov ${ }^{2}$, \\ Falko Fend ${ }^{3}$, Tonino Ercolino ${ }^{4}$, Massimo Mannelli ${ }^{5}$, Anne-Paule Gimenez- \\ Roqueplo ${ }^{6,7,8}$, Mercedes Robledo 9 , Ronald de Krijger $^{10}$, Felix Beuschlein ${ }^{11}$, Michael \\ J. Atkinson' ${ }^{2}$, Natalia S. Pellegata ${ }^{1}$ \\ ${ }^{1}$ Institute of Pathology, Helmholtz Zentrum München, Neuherberg, Germany \\ ${ }^{2}$ Institute of Radiation Biology, Helmholtz Zentrum München, Neuherberg, Germany \\ ${ }^{3}$ Institute of Pathology and Neuropathology Comprehensive Cancer Center Tübingen and University of Tübingen, Tübingen, \\ Germany \\ ${ }^{4}$ Azienda Ospedaliero-Universitaria di Careggi, Endocrine Unit, Florence, Italy \\ ${ }^{5}$ Department of Experimental and Clinical Biomedical Sciences, University of Florence, Florence, Italy \\ ${ }^{6}$ INSERM, UMR U970, Paris Cardiovascular Research Center-PARCC, Paris, France \\ 7 Université Paris Descartes, Sorbonne Paris Cité, Faculté de Médecine, Paris, France \\ ${ }^{8}$ Assistance Publique Hôpitaux de Paris, Hôpital européen Georges Pompidou, Department of Genetics, Paris, France \\ ${ }^{9}$ Hereditary Endocrine Cancer Group, Spanish National Cancer Research Centre (CNIO), Madrid, Spain \\ ${ }^{10}$ Department of Pathology, Erasmus MC, University Medical Center Rotterdam, Rotterdam, The Netherlands \\ ${ }^{11}$ Endocrine Research Unit, Medizinische Klinik und Poliklinik IV, Klinikum der Universität München, München, Germany \\ Correspondence to: \\ Natalia S. Pellegata, e-mail: natalia.pellegata@helmholtz-muenchen.de \\ Keywords: pheochromocytoma, bone morphogenic protein 7, PI3K pathway, integrin beta 1, MENX rats \\ Received: May 22, $2015 \quad$ Accepted: August 07, $2015 \quad$ Published: August 18, 2015
}

\section{ABSTRACT}

BMP7 is a growth factor playing pro- or anti-oncogenic roles in cancer in a cell type-dependent manner. We previously reported that the BMP7 gene is overexpressed in pheochromocytomas (PCCs) developing in MENX-affected rats and human patients. Here, analyzing a large cohort of PCC patients, we found that $72 \%$ of cases showed elevated levels of the BMP7 protein. To elucidate the role of BMP7 in PCC, we modulated its levels in PCC cell lines (overexpression in PC12, knockdown in MPC and MTT cells) and conducted functional assays. Active BMP signaling promoted cell proliferation, migration, and invasion, and sustained survival of MENX rat primary PCC cells. In PCC, BMP7 signals through the PI3K/AKT/mTOR pathway and causes integrin $\beta 1$ upregulation. Silencing integrin $\beta 1$ in PC12 cells suppressed BMP7-mediated oncogenic features. Treatment of MTT cells with DMH1, a novel BMP antagonist, suppressed proliferation and migration. To verify the clinical applicability of our findings, we evaluated a dual PI3K/mTOR inhibitor (NVP-BEZ235) in MENX-affected rats in vivo. PCCs treated with NVP-BEZ235 had decreased proliferation and integrin $\beta 1$ levels, and higher apoptosis. Altogether, BMP7 activates pro-oncogenic pathways in PCC. Downstream effectors of BMP7-mediated signaling may represent novel targets for treating progressive/inoperable PCC, still orphan of effective therapy.

\section{INTRODUCTION}

Pheochromocytomas (PCCs) are tumors arising from neural crest-derived chromaffin cells of the adrenal medulla and sympathetic ganglia (the latter referred to as paragangliomas, PGLs). PCCs/PGLs occur sporadically or as a result of an inherited germline mutation in one of at least 12 genes (35\%-40\% of cases), including $V H L$, NF1, RET, SDHA, SDHB, SDHC, SDHD, SDHAF2, $H I F 2 \alpha, K I F 1 B \beta, T M E M 127, M A X$ and $F H[1]$. In contrast 
to familial PCC/PGL, less is known about the somatic mechanisms driving the more frequent sporadic tumors. Recently, using an integrative genomics approach, common alterations were discovered in sporadic PCC that now await functional validation $[2,3]$.

Transcriptome analyzes have determined that gene expression signatures of human PCCs reflect the underlying driver mutation [4,5]. Specifically, PCCs and PGLs can be divided into two main clusters, designated as Cluster 1 and Cluster 2; Cluster 1 tumors are associated with germline mutations in $V H L, S D H x$, and probably $H I F 2 \alpha$ and $F H$ genes, and Cluster 2 tumors are associated with mutations in NF1, RET, KIF1B $\beta$, and TMEM127 [1]. Sporadic PCCs mainly group in Cluster 2.

Although usually benign, approximately $10-15 \%$ of PCC cases are considered malignant on the basis of the presence of distant metastases and have a 5-year survival rate of $<50 \%$ [6]. Surgery remains the first-line therapy for patients with localized disease or with isolated and resectable distant metastases [7]. For patients with disseminated tumor spread, extensive local invasion, or recurrence, systemic conventional chemotherapy has been tested without clear benefit on overall survival. Radiotherapy with the radiopharmaceutical ${ }^{131}$ I-metaiodobenzylguanidine ( $\left.{ }^{131} \mathrm{I}-\mathrm{MIBG}\right)$ was shown to have positive therapeutic effects, but tumor regression occurred in only $30 \%$ of patients [8]. The tyrosine kinase inhibitor sunitinib has shown some efficacy in patients with a progressive disease [9], whereas the mTOR inhibitor everolimus exhibited low efficacy $[10,11]$. Taken together, there is a considerable clinical need for more effective therapies against aggressive/malignant PCC; elucidating the molecular mechanisms involved in PCC tumorigenesis will be instrumental in identifying targets for such therapies.

Rats affected by the MENX multiple endocrine neoplasia syndrome develop bilateral PCCs with complete penetrance [12]. The tumors show progression from hyperplasia (4 months of age) to tumors (7-8 months of age) with time. Rat PCCs share similarities with their human counterparts in terms of histopathological features [13, 14], gene copy number variations [13], expression signatures [14], and uptake of radiolabeled tracers for imaging $[15,16]$. The rat tumors show elevated proliferation rates (average $11.3 \%$, range $3.7 \%$ to $16.7 \%$ ) [15], thus mostly resembling human aggressive PCCs. Despite these high proliferation rates, no metastases of rat pheochromocytomas have been so far documented, probably due to the short life span of MENX rats [17]. To elucidate the molecular pathogenesis of PCC, we previously performed transcriptome analyzes of adrenomedullary hyperplasia and tumors from MENXaffected rats. These studies identified the $B m p 7$ gene, never before associated with adrenomedullary tumorigenesis, as being significantly overexpressed in rat hyperplastic and neoplastic lesions versus normal adrenal medulla [14].
Bmp7 was already up-regulated in the adrenal medulla of 1-month-old mutant rats before pathological changes occur. Importantly, the $B M P 7$ gene was also found to be up-regulated in $88 \%$ of human sporadic PCCs and $69 \%$ of the familial cases [14].

BMP7 (bone morphogenic protein 7) belongs to the transforming growth factor $\beta$ (TGF $\beta$ ) superfamily of secreted growth factors [18]. Besides a role in embryonic development, differentiation, and organogenesis, BMPs were recently implicated in regulating growth, migration, and apoptosis of cancer cells [19-21]. BMPs bind to types I and II transmembrane serin/threonine kinase receptors (BMPR-I or BMPR-II), which dimerize upon ligand binding, and the constitutively activated BMPR-II phosphorylates BMPR-I [22]. In the canonical BMP pathway, BMPRI phosphorylates receptorassociated SMAD transcription factors [SMADs 1, 5, and 8 (mouse)/9 (human)], which then bind to the common mediator SMAD4 and translocate into the nucleus [22], where these complexes bind to the DNA and regulate target gene transcription [23].

In human cancers, BMPs exhibit pro- or anticarcinogenic functions depending on the cell/tissue type, dosage, and micro-environment [24]. Although the functional significance of BMP7 has been studied in several tumors, including breast, colorectal, gastric, and prostate carcinomas [25-28], its role in adrenomedullary tumorigenesis has not yet been explored. Using a large cohort of well-characterized PCC/PGL patients, we here confirmed that the BMP7 protein is highly expressed in $>70 \%$ of tumors; this correlates with extra-adrenal location and tumor size. We demonstrated that endogenous BMP7 overexpression promotes PCC cell proliferation, migration, and invasion and identified the PI3K/AKT/ mTOR pathway and integrin $\beta 1$ as downstream effectors of active BMP signaling. Proof-of-principle studies using a specific BMP antagonist (in vitro) and a $\mathrm{PI} 3 \mathrm{~K} / \mathrm{mTOR}$ inhibitor (in vivo) revealed that targeting BMP7-mediated pathways could be an effective strategy to treat PCCs.

\section{RESULTS}

\section{Bmp7 expression in rat PCCs}

We investigated whether Bmp7 transcript overexpression, previously observed in MENX-associated rat PCCs [14], translates into increased levels of the encoded protein. By immunohistochemistry (IHC) and immunofluorescence (IF), we could confirm that Bmp7 protein levels and those of its canonical downstream targets [i.e., phosphorylated (P)-Smad1/5/8] were elevated in the tumors of mutant animals compared with the adrenal medulla of wild-type animals (Figure 1A). Concordantly, circulating Bmp7 protein was significantly elevated in the peripheral blood of mutant when compared with wild-type animals $(P=0.0006)$ (Figure 1B). Collectively, these data 

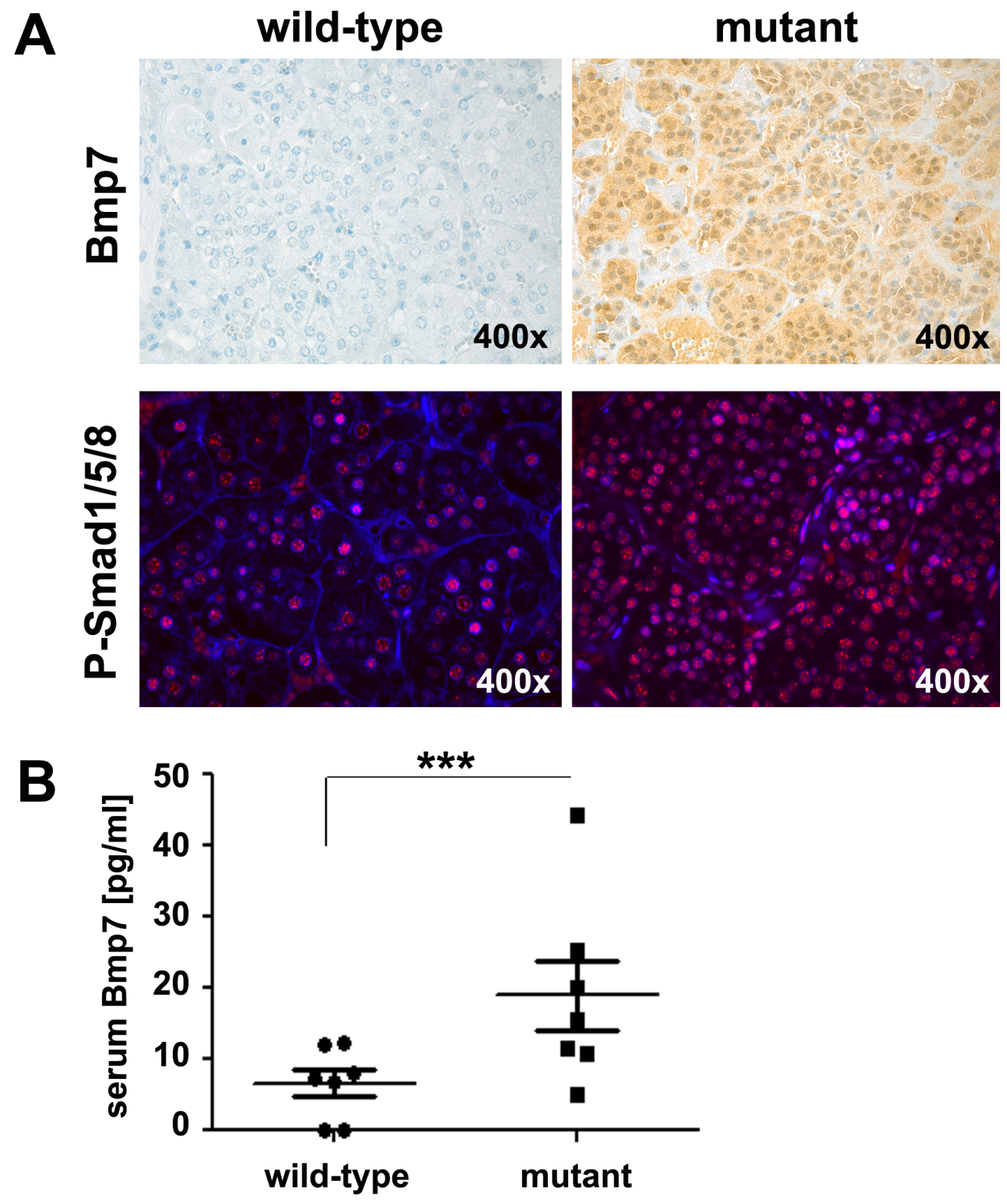

Figure 1: Expression of Bmp7 in rat PCC and its secretion. A. IHC or IF on adrenal medullary tissue from wild-type and mutant rats was performed using a rat anti-BMP7 antibody or an anti-P-Smad1/5/8 antibody, respectively. These tissues are representative of five tissues per animal group. Original magnification: $400 \times \mathbf{B}$. Plasma Bmp7 levels were measured in seven MENX mutant rats and seven wildtype rats fasted for $12 \mathrm{~h}$. Measurements were performed using a rat Bmp7 ELISA-KIT. ***, $P<0.001$.

demonstrate that the Bmp7 protein is expressed at a high level in rat PCCs and is secreted.

\section{BMP7 expression in human PCCs}

Similar to the rat tumors, human sporadic and familial PCCs also overexpress the BMP7 gene [14]. Following preliminary immunohistochemical studies on 10 human primary PCCs, we extended our analysis to a large and well-characterized cohort of 208 PCCs/PGLs spotted on tissue microarrays (TMAs). A total of 184 tumor samples (150 PCCs and 34 PGLs) satisfied our inclusion criteria (see Material and Methods). IHC was performed and TMAs were scored for staining intensity. The anti-BMP7 antibody we used has a reported 25\% cross-reactivity with BMP6 and no cross-reactivity with other BMPs. However, given that the BMP6 gene was found to be expressed at the limit of detection in a series of 10 frozen human PCCs by TaqMan (data not shown), the signal observed by IHC is specific for BMP7. In our cohort, $72 \%$ of the tumors displayed moderate $(++)$ to strong $(+++)$ immunoreactivity for BMP7 (Figure 2A-2D). We then studied the possible correlations between BMP7 levels and either clinical parameters of the patients or tumor characteristics. No association between BMP7 expression and gender, age, plasma catecholamines, or 
chromogranin A levels was evident. In contrast, we found that $88 \%$ of the PGLs, but only $68 \%$ of PCCs, exhibit an elevated BMP7 expression ( $P=0.02$, Figure $2 \mathrm{E})$. BMP7 levels were high $(++/+++)$ in $93 \%$ of tumors bigger than $8 \mathrm{~cm}$ in diameter (large), but only in $56 \%$ of the tumors smaller than $3 \mathrm{~cm}$ in diameter (small, $P=0.018$, Figure 2F). Concerning the underlying predisposing mutation, we found that $92 \%$ of Cluster- 1 tumors show high BMP7 levels as opposed to $74 \%$ of Cluster- 2 tumors; however, this difference was not statistically significant (Figure 2G). In our series, 11 cases were malignant and nine of them showed high BMP7 expression, suggesting a trend for higher BMP7 levels in malignant tumors (Figure 2H).

Thus, in human PCCs, BMP7 is highly expressed and its levels positively associate with tumor size and origin (extra-adrenal).

\section{BMP7 promotes proliferation of $\mathrm{PCC}$ cell lines and the viability of primary rat $\mathrm{PCC}$ cells}

As no data were available on the possible role of $\mathrm{Bmp} 7$ in PCC, we performed in vitro functional assays. We first employed as experimental model the PC12 cell line, established from a rat PCC [29]. Consistent with published data [30], PC12 cells were found to express BMP receptors, thereby representing a suitable model to study autocrine/paracrine effects of endogenous BMP signaling (Supplementary Figure S1). PC12 cells express the endogenous Bmp 7 gene at relatively low levels (Figure 3A). Thus, they were transfected with an empty vector (mock) or with a vector expressing a Myc-tagged human $B M P 7$ cDNA to mirror the situation in rat and human primary PCCs (Figure 3A). Ectopic BMP7 overexpression slightly increased $\mathrm{PC} 12$ proliferation rates $(P<0.01)$ (Figure 3E).
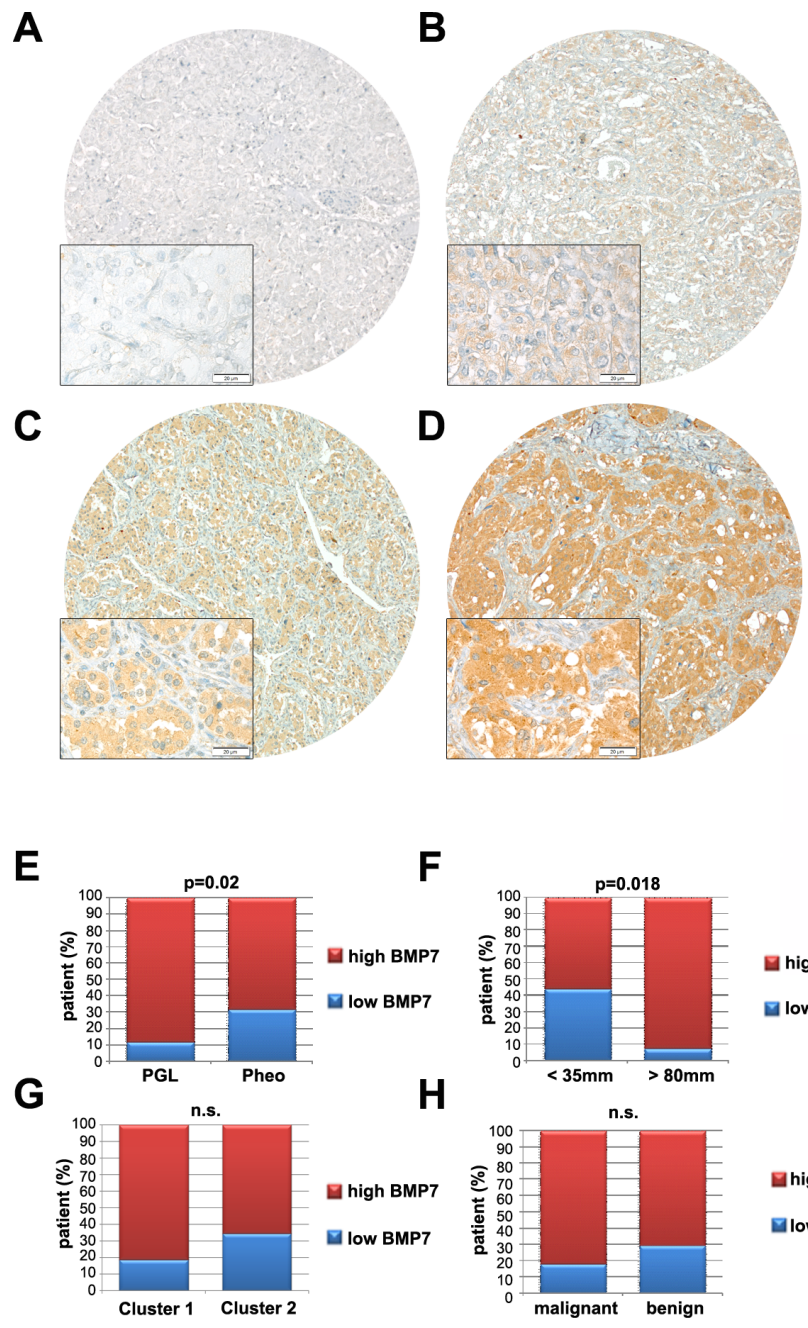

$\mathbf{F}$

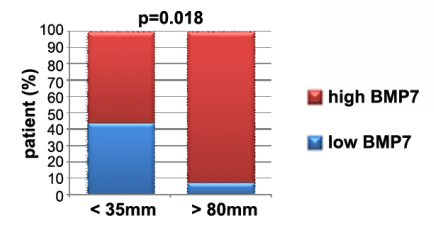

H

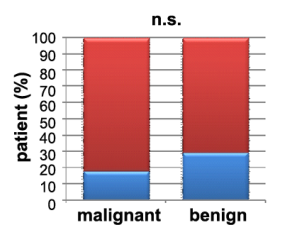

Dhigh BMP7

Ilow BMP7

Figure 2: Expression of BMP7 in human PCC. A-D. IHC for BMP7 was performed on tissue microarrays using a human antiBMP7 antibody. After selection, 150 PCCs and 34 PGLs were scored. We only considered tumors for which both cores could be scored after IHC staining. Images were recorded and we show low (original magnification, $\times 40$ ) and high (original magnification, $\times 400)$ power views of four different PCCs representative of the intensities of BMP7 staining (A,-; B,+; C,++; D,+++). E-H. BMP7 expression of the 184 tumors was correlated with clinical variables, including (E) location (Extra-adrenal PCC $=$ PGL; Adrenal PCC $=$ Pheo), $(\mathrm{F})$ tumor size ( $<35 \mathrm{~mm} ;>8 \mathrm{~mm}),(\mathrm{G})$ genetic background (cluster 1; cluster2), and $(\mathrm{H})$ malignancy (malignant; benign). n.s., not significant. 

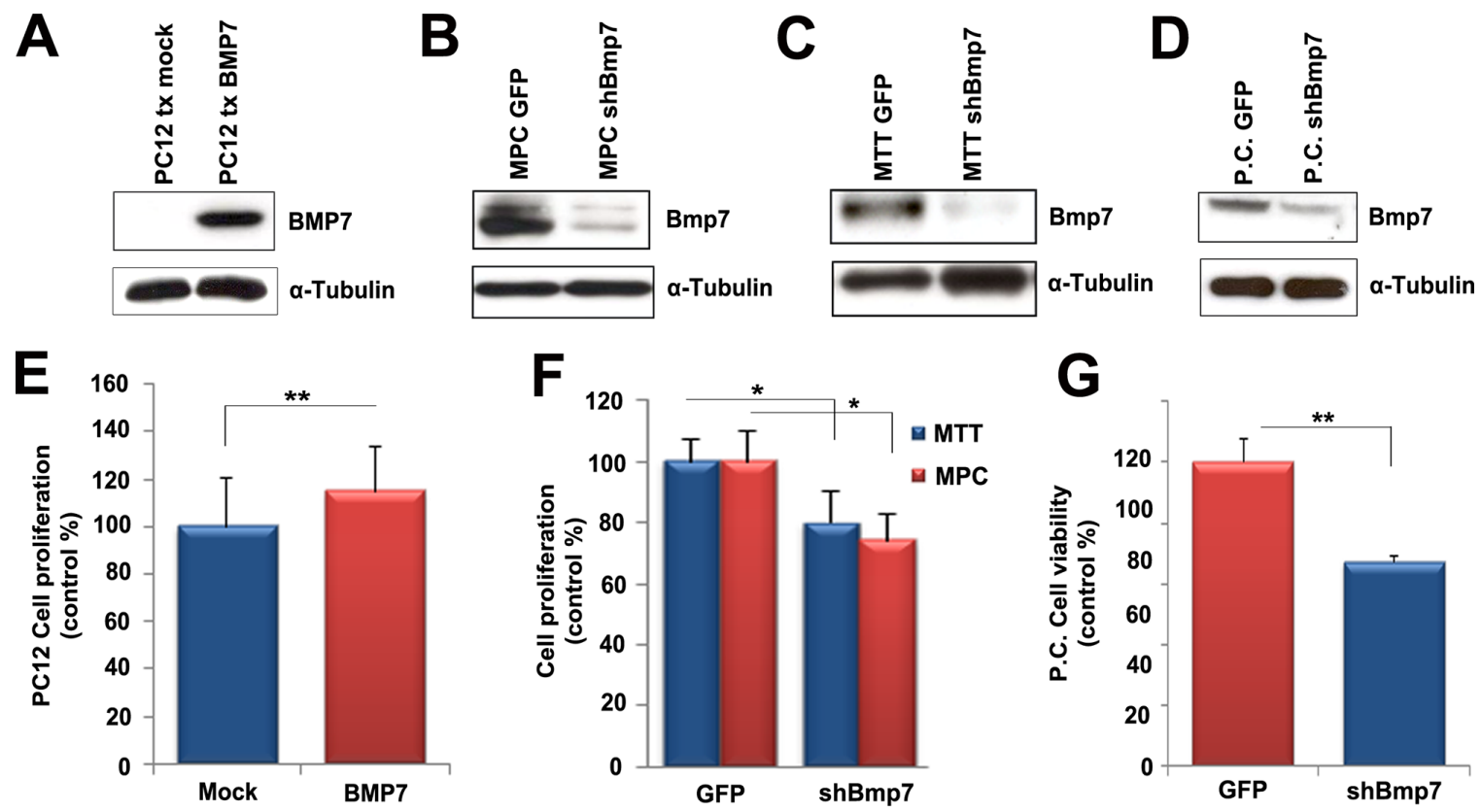

Figure 3: Bmp7 promotes proliferation of PCC cells in vitro. A. We transfected PC12 cells with a Myc-BMP7 plasmid, and $24 \mathrm{~h}$ later cells were analyzed by western blotting using a specific anti-Myc antibody. B. MPC, C. MTT and D. primary rat tumor (P.C.) cells were infected with lentiviral vectors containing shBMP7-GFP (\#2.9) or GFP alone. Western blotting was performed $72 \mathrm{~h}$ later using the rat anti-BMP7 antibody. $\alpha$-Tubulin was used as loading control. E. PC12 cells were transfected with the BMP7 plasmid (BMP7) or with the mock vector (Mock) and proliferation was assessed $24 \mathrm{~h}$ later using the WST-1 assay. Data were analyzed independently with six technical replicates each, and are expressed as the mean \pm SD. Proliferation was normalized against the values of mock transfected cells arbitrarily set to $100 \%$. **, $P<0.01$. F. MPC and MTT cells were infected as in B and C, and $72 \mathrm{~h}$ later we assessed proliferation using the WST-1 assay. Data were analyzed independently with six technical replicates each, and are expressed as the mean \pm SD. Proliferation was normalized against the values of GFP-infected cells arbitrarily set to $100 \%{ }^{*}, P<0.05$. G. Primary cells (P.C.) were infected as in D and cell viability was measured $72 \mathrm{~h}$ after infection. The average of three independent cultures from three mutant rats (8 months of age) is shown. Proliferation was normalized against the values of GFP-infected cells which were arbitrarily set to $100 \%$. $* *, P<0.01$.

MPC and MTT mouse PCC cell lines were found to have relatively high endogenous Bmp7 levels (Figure 3B, 3C) and were therefore utilized for knockdown experiments. Similar to PC12 cells, MPC and MTT cells were found to express BMP receptors (Supplementary Figure S1). Because these cells were difficult to transfect, we generated lentiviral vectors expressing small hairpin (sh)RNA molecules directed against both mouse and rat $B m p 7$ gene together with the green fluorescent protein (GFP) to monitor infection efficiency (around $80 \%-90 \%$, data not shown). Two sequences (\#1.8 and \#2.9) were originally cloned and tested in preliminary experiments that showed that GFP vector alone had no effect on cell proliferation, while both $\operatorname{sh} B m p 7$ constructs decreased cell proliferation (Supplementary Figure S2A). Since sequence \#2.9 reduced Bmp 7 expression more efficiently (Supplementary Figure S2B), it was selected for further experiments.

We found that reduced endogenous $B m p 7$ expression decreased the proliferation of MPC $(30 \%$ reduction; $P<0.05)$ and MTT $(20 \%$ reduction; $P<0.05)$ cells (Figure 3F). Bmp 7 knockdown in shBmp7-infected cells was confirmed by western blotting (Figure 3B, 3C). We then evaluated the potential tumorigenic role of Bmp7 in a more physiological system: primary cultures of MENXderived PCCs. We first confirmed that the tumor cells in vitro maintain the high Bmp7 expression seen in the primary tumors of origin (Figure 3D) and that they express BMP receptors (Supplementary Figure S1). Preliminary experiments showed that $\operatorname{sh} B m p 7 \# 2.9$ lentiviral vector was the most effective vector also in this experimental system and was further employed (Supplementary Figure S2C, S2D). Then, PCC cells from three mutant rats were dispersed in culture plates and infected with shBmp 7-GFP or GFP-only lentiviral vectors. Concomitantly, with a reduction of Bmp7 expression (Figure 3D), we observed a significant decrease in primary cell viability upon infection with shBmp7-vector (35\%-45\% reduction versus control GFP-vector) (Figure 3G). Therefore, autocrine Bmp 7 signaling plays a role in sustaining the survival of rat primary adrenomedullary tumor cells.

\section{BMP7 enhances migration and invasion of PCC cells}

Next, we investigated whether BMP7 promotes cell migration and/or invasion of PCC cells. BMP7or empty-vector-transfected PC12 cells were used 
for migration assays employing a Boyden chamber. Elevated BMP7 expression stimulated PC12 cell migration (1.8-fold that of empty vector-transfected cells) (Figure 4A, 4C). Invasion assays through a Matrigel basement membrane matrix were conducted in parallel. BMP7-transfected PC12 cells displayed higher invasion potential (2.8-fold) than empty-vectortransfected cells $(P<0.01)$ (Figure 4B, 4E). Similar experiments conducted on MPC cells showed that $B m p 7$ downregulation by the $\operatorname{sh} B m p 7$-containing vector reduced their migration and invasion potential by up to $65 \%(P<0.001)$ and $70 \%(P<0.001)$, respectively, compared with GFP-vector-infected cells (Figure 4A, 4B, 4D, 4F). Similarly, migration (average 70\% reduction; $P<0.001)$ and invasion $(80 \% ; P<0.001)$ of MTT cells were reduced upon $B m p 7$ knockdown (Figure 4A, 4B, 4D, 4F).

Thus, high endogenous Bmp7 levels promote proliferation, but especially migration and invasion (i.e., the metastatic potential) of PCC cells.

\section{BMP7 pathway activation increases integrin ß1 expression}

Given that BMP7 overexpression stimulates PCC cell migration/invasion, we decided to comprehend the involved molecular mechanisms. We focused on integrins, cell surface receptors that are critical regulators of cell motility [31]. Among the integrin subunits, integrin $\beta 1$ has been associated with the progression of several cancer types. As it was found expressed in all three PCC cell lines (data not shown), it was selected for further studies. If integrin $\beta 1$ was involved in Bmp7-mediated increase in PC12 cell migration/invasion, we expected it to be induced by activated Bmp7 signaling. Indeed, ectopic BMP7 overexpression increased not only PC12 cell migration/ invasion (Figure 4A, 4B) but also the amount of integrin $\beta 1$ (Figure 5A). As assessed by IF, BMP7 up-regulation enhanced integrin $\beta 1$ expression in transfected and nearby un-transfected cells, consistent with a paracrine signaling mechanism. In contrast, empty-vector-transfected cells

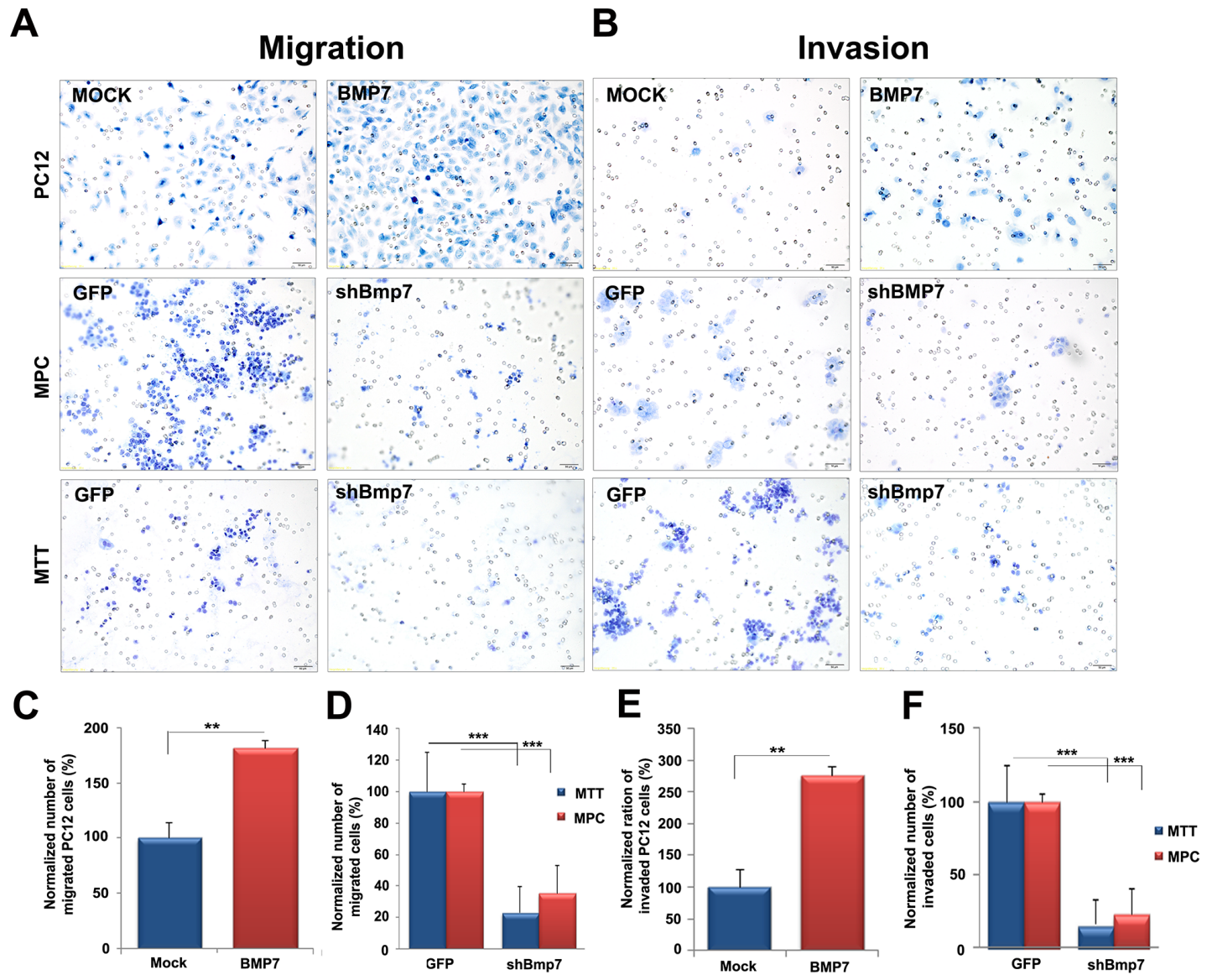

Figure 4: Bmp7 enhances migration and invasion of PCC cells in vitro. We transfected PC12 cells with a Myc-BMP7 plasmid and $24 \mathrm{~h}$ later A, C. migration and B, E. invasion were assessed. MPC and MTT cells were infected with lentiviral vectors containing sh $B m p$ 7-GFP or GFP alone, and $72 \mathrm{~h}$ later we assessed A, D. migration and $\mathbf{B}$, F. invasion. The percentage of cells that migrated or invaded was normalized against the values of mock transfected cells or of GFP-infected cells arbitrarily set to $100 \%$. The experiment was performed two times with three technical replicates with similar results. Five random fields of each test at $\times 400$ magnification were counted ( \pm SD). $* *, P<0.01 ; * * *, P<0.001$. 
exhibited extremely faint staining for integrin $\beta 1$ by both IF and western blotting (Figure 5A). PC12 cells were also treated with recombinant human (rh) BMP7, which up-regulated the canonical downstream pathways (i.e., P-Smad1/5/8) similar to BMP7 overexpression (Figure 5B). Following rhBMP7 addition to the culture media, integrin $\beta 1$ expression was assessed at different time points and was found to be induced 15 min post-stimulation (Figure 5C). To verify that integrin $\beta 1$ mediates the BMP7-dependent increase in cell migration and invasion, PC12 cells were co-transfected with Myc-BMP7 and scrambled siRNA oligos, or with Myc-BMP7 and siRNA oligos against the

A
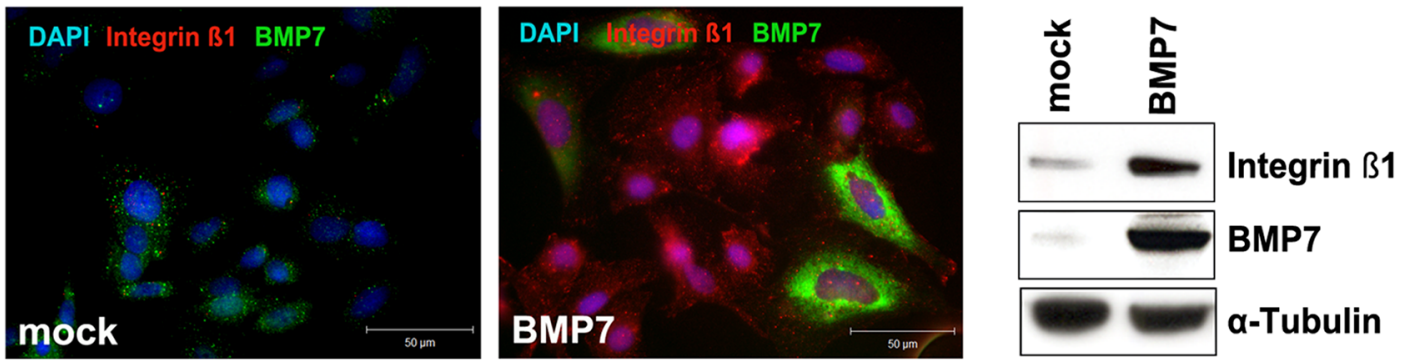

B

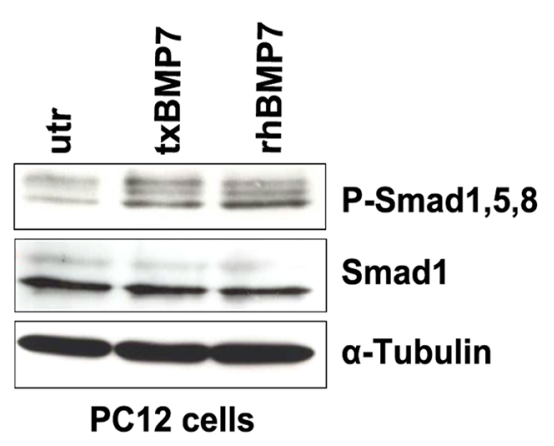

D

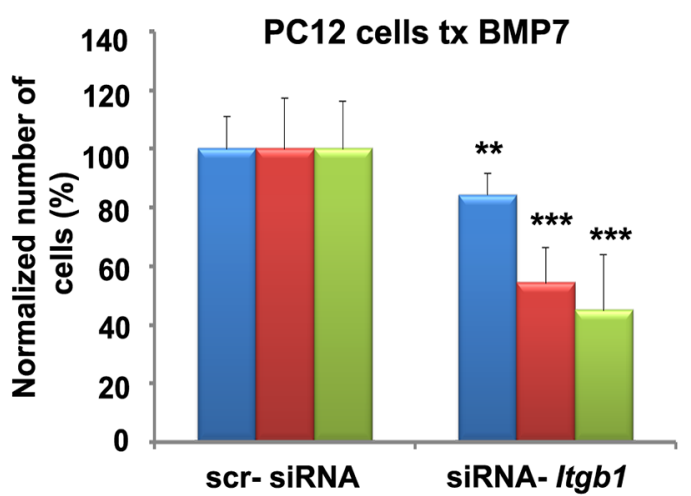

C

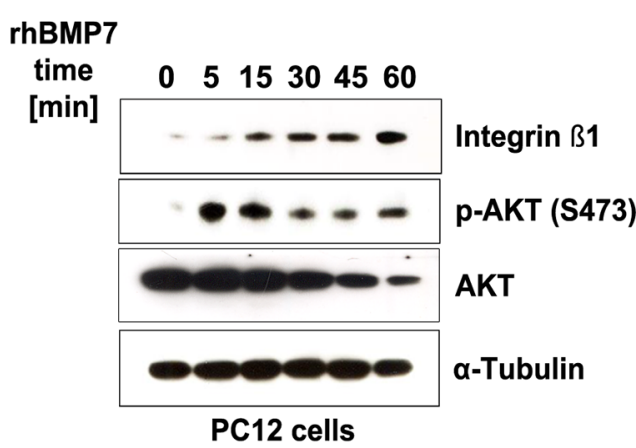

Proliferation

Migration

Invasion

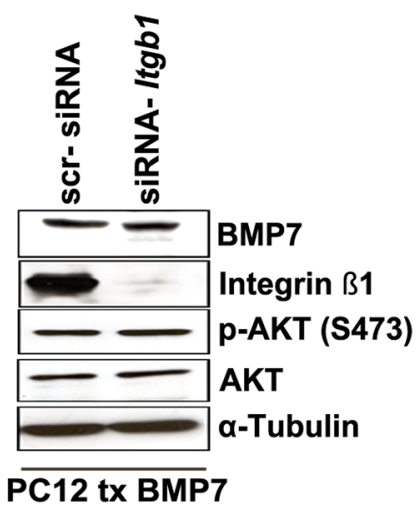

Figure 5: Downstream BMP7 signaling in PCC cells. A. PC12 cells were transfected with a BMP7-containing (BMP7) or an empty (mock) vector. Twenty-four h post transfection IF was performed using specific antibodies targeting integrin $\beta 1$ (1:400) or BMP7 (1:100). Cell nuclei were counterstained with DAPI. In parallel, the expression of integrin $\beta 1$ and BMP7 proteins was determined by western blotting using specific antibodies. $\alpha$-Tubulin was used as loading control. B. PC12 cells were either transfected (txBMP7) with a Myc-BMP7 plasmid or treated with $100 \mathrm{ng} / \mathrm{mL}$ recombinant human BMP7 (rhBMP7). After $24 \mathrm{~h}$, cells were collected and analyzed by western blotting using antibodies against P-Smad1/5/8 and Smad1. $\alpha$-Tubulin was used as a loading control. C. PC12 cells were treated with rhBMP7 for 5, 15, 30, 45 , or 60 min. Western blot analysis was performed using specific antibodies raised against integrin $\beta 1$, AKT and P-AKT. $\alpha$-Tubulin was used as loading control. D. We co-transfected PC12 cells with BMP7 and scr-siRNA or siRNA-Itgbl and 24 h later proliferation, migration and invasion were assessed. Values for cells with knockdown of Itgbl were normalized against the values of scr-siRNA-transfected cells arbitrarily set to $100 \%$. The experiments were performed two times with three technical replicates with similar results. For proliferation, the average of the 2 experiments is shown. For migration/invasion, five random fields of each test at $\times 400$ magnification were counted (average \pm SD). $* *$, $P<0.01 ; * * *, P<0.001$. In parallel, the levels of BMP7, integrin $\beta 1$, P-AKT and AKT were assessed in the transfected cells by western blotting with specific antibodies as described above. $\alpha$-Tubulin was used as a loading control. (Continued) 


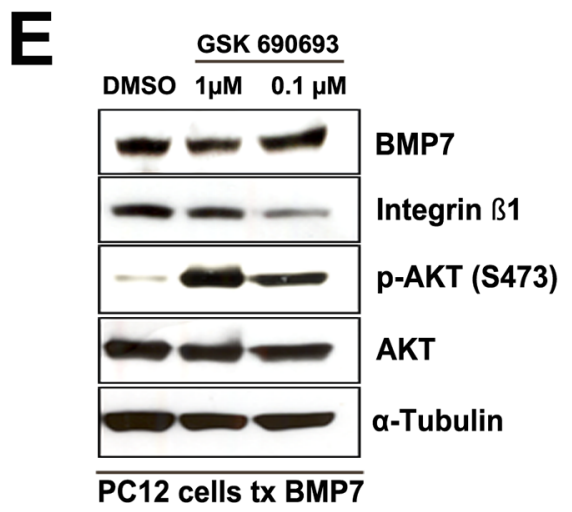

$\mathbf{F}$

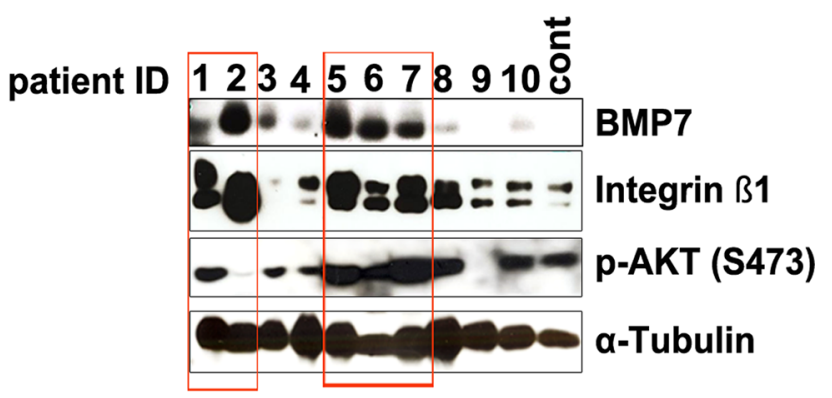

Figure 5: (Continued) Downstream BMP7 signaling in PCC cells. E. PC12 cells were treated with the indicated concentrations of the P-AKT inhibitor GSK690693 and western blot analysis was performed $24 \mathrm{~h}$ later to determine the expression of BMP7, integrin $\beta 1$, P-AKT, and AKT. $\alpha$-Tubulin was used as a loading control. F. Expression of BMP7, integrin $\beta 1$, and P-AKT in 10 human primary PCCs and one human normal medulla (cont.) was assessed by western blotting using specific antibodies. $\alpha$-Tubulin was used as a loading control.

Itgb1 gene (si $\operatorname{tg} b 1)$ encoding integrin $\beta 1$. Itgb1 silencing significantly reduced $\mathrm{PC} 12$ cell proliferation, migration and invasion capacity (Figure 5D). Efficient Itgbl knockdown was confirmed by western blotting (Figure 5D).

Similar to integrin $\beta 1$, P-AKT rapidly increased in rhBMP7-treated PC12 cells (Figure 5C). Integrin $\beta 1$ is regulated by $\mathrm{PI} 3 \mathrm{~K} / \mathrm{AKT} / \mathrm{mTOR}$ signaling in other cancers $[32,33]$. Therefore, we investigated whether this also occurs in PCC. Upon incubation with the selective pan-AKT kinase inhibitor GSK690693, integrin $\beta 1$ level decreased in PC12 cells with BMP7 overexpression (Figure 5E), consistent with a role for AKT in modulating integrin $\beta 1$ expression. In PC12 cells, as in other cancer cells [34], P-AKT did not decrease following GSK690693 treatment because of the blockade of a negative feedback loop downstream of AKT.

As no data were available on integrin $\beta 1$ expression in human PCCs, 10 tumors with enough frozen material were analyzed by western blotting and compared with normal adrenal medulla. Samples were also probed for BMP7 and P-AKT expression. The results revealed that integrin $\beta 1$ is expressed in PCCs; its level tends to correlate with that of BMP7 (Figure 5F). Primary PCCs having high BMP7 and integrin $\beta 1$ levels mostly showed also elevated P-AKT.

\section{BMP signaling inhibition suppresses PCC cell proliferation and promotes apoptosis}

Due to its involvement in human cancers, the BMP pathway has been considered for therapeutic intervention, and small-molecule BMP antagonists are being evaluated in preclinical studies. Among them, DMH1, a second-generation analog of dorsomorphin, highly selectively inhibits BMP type I receptors (BMPR-I), but no other off-target receptors [35]. To verify whether blocking BMP receptor signaling might be a potential strategy for targeted therapy of PCC, we treated MTT cells (high endogenous Bmp7 levels) with DMH1 and then assessed cell proliferation and migration. DMH1 treatment significantly suppressed MTT cell proliferation in a dose- and time-dependent manner (Figure 6A), and even more strongly inhibited cell migration (Figure 6B). Concomitantly, we observed a dose-dependent downregulation of the expression of P-Smad $1 / 5 / 8$ and integrin $\beta 1$, both readouts of active BMP signaling in PCC cells, as well as of P-AKT in DMH1-treated MTT cells (Figure 6C).

Next, we determined the effect of DMH1 on rat primary PCC cells (high Bmp7 expression). Independent cultures from 5 affected rats were incubated with different DMH1 concentrations, and this resulted in a strong decrease in cell viability (Figure 6D).

In conclusion, a novel small-molecule BMP antagonist elicits anti-proliferative and anti-migratory responses in PCC cells with active BMP signaling in vitro.

\section{Tumors expressing high Bmp7 levels respond well to PI3K inhibition in vivo}

The increase in P-AKT following either BMP7 gene transfection or rhBMP7 treatment suggests that BMP7 signaling occurs through the PI3K/AKT/mTOR pathway in PCC cells. Given our data on the high BMP7 levels in PCCs and on its pro-oncogenic function, targeting the PI3K pathway may represent an effective therapeutic strategy for treating these tumors. To test this hypothesis, we employed MENX rats as a prototypic in vivo model of endogenous PCCs having elevated BMP7 expression and an activated PI3K pathway [36]. We previously reported that NVP-BEZ235, a dual PI3K-mTOR inhibitor, has antitumor activity against primary PCC cultures from MENX rats in vitro [36]. Here we daily administered NVP-BEZ235 $(n=4)$ or PEG vehicle $(n=4)$ to MENX-affected rats by oral gavage for 2 weeks. 
Post-treatment, we observed a reduction of both P-S6 (Figure 7A, 7B), a downstream effector of mTOR, and integrin $\beta 1$ (Figure 7C, 7D), readout of BMP signaling, in tumors following NVP-BEZ235 but not vehicle administration, thereby confirming BMP/PI3K pathway blockade. Concomitantly, PCCs of drug-treated rats displayed a significant reduction in proliferation (Ki67 staining) and increase in apoptosis (Annexin $\mathrm{V}$ and active caspase 3 staining) (Figure 7F-7I). These findings in vivo recapitulate the signaling pathway that we identified in PCC cells in vitro, wherein active BMP7 signaling induces integrin $\beta 1$ expression through $\mathrm{PI} 3 \mathrm{~K} / \mathrm{AKT} / \mathrm{mTOR}$ pathway activation.
Moreover, they demonstrate that targeting the PI3K signaling cascade evokes antitumor effects in PCCs with active BMP signaling in vivo.

\section{DISCUSSION}

The molecular mechanisms accompanying sporadic PCC remain largely undefined, thereby hampering the identification of novel therapeutic targets for this occasionally aggressive and malignant tumor. In this study, we show that BMP7 is highly expressed in PCC, where it promotes pro-oncogenic features
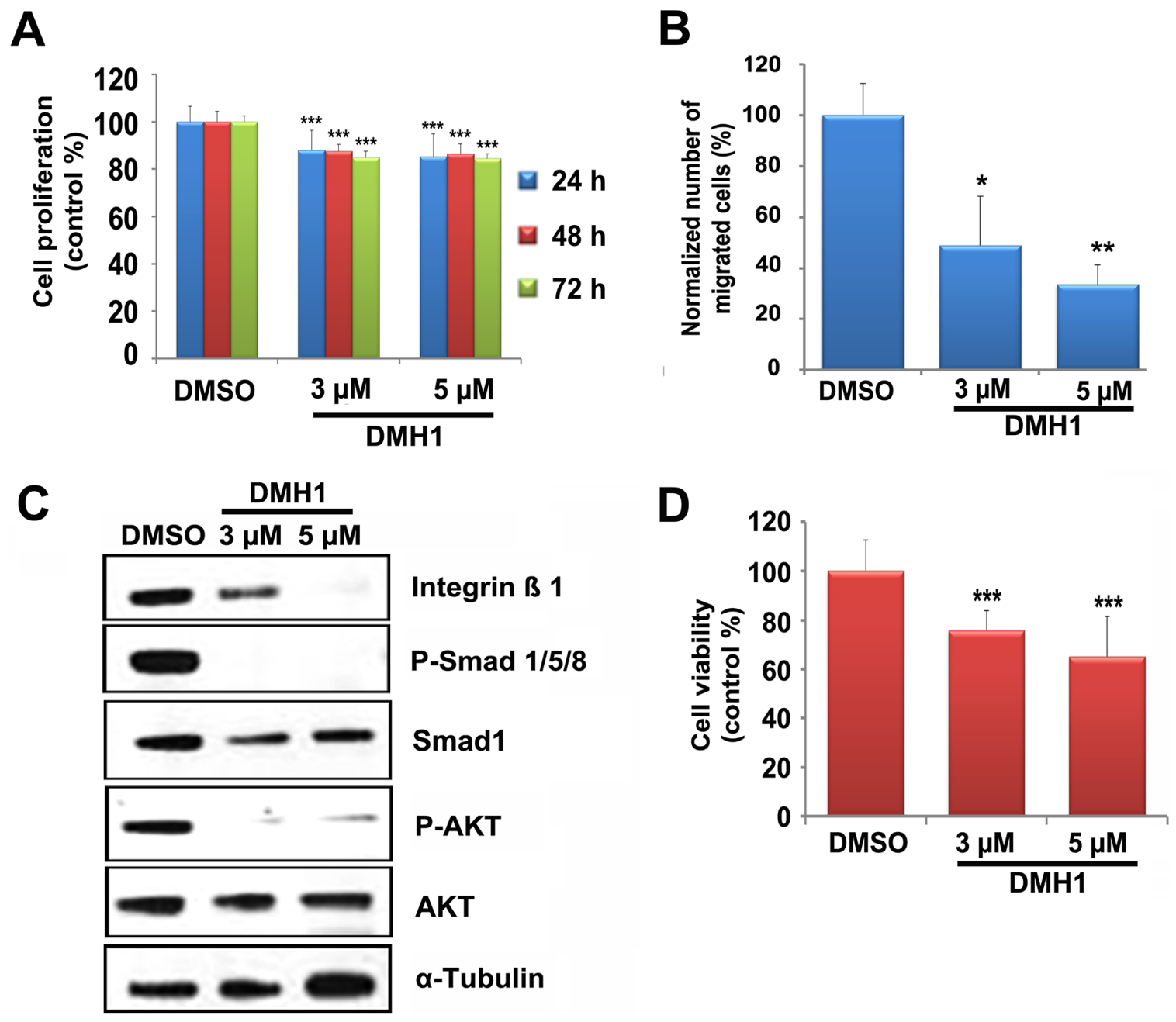

Figure 6: Effect of DMH1 on BMP downstream signaling and PCC cell growth. A. MTT cells were treated with DMH1 (3 $\mu$ M or $5 \mu \mathrm{M})$ or with DMSO vehicle. Proliferation was assessed at the indicated times by the WST-1 assay. The experiments were performed two times with six technical replicates each, and are expressed as the mean $\pm \mathrm{SD}$. The values are normalized against those of DMSOtreated cells set to $100 \%$. ***, $P<0.001$. B. MTT cells treated as in A for $24 \mathrm{~h}$ were used for migration assays as indicated in Figure 4. The percentage of cells that migrated was normalized against the values of DMSO-treated cells arbitrarily set to $100 \%$. The experiment was performed two times with three technical replicates with similar results. Five random fields of each test at $\times 400$ magnification were counted $( \pm \mathrm{SD}) . *, P<0.05 ; * *, P<0.01$. C. MTT cells were treated with DMH1 $(3 \mu \mathrm{M}$ or $5 \mu \mathrm{M})$ or with DMSO vehicle for 24 h. Proteins were then collected and probed for the expression of integrin $\beta 1$, P-Smad1/5/8, Smad1, P-AKT and AKT. $\alpha$-Tubulin was used as a loading control. D. Rat primary tumor cells were treated with DMH1 $(3 \mu \mathrm{M}$ and $5 \mu \mathrm{M})$ or DMSO for $72 \mathrm{~h}$ and cell viability was assessed using the WST-1 assay. Shown is the average of five independent cultures from five mutant rats ( 8 months of age). The values are normalized against those of DMSO-treated cells set to $100 \%$. Data were analyzed independently with six technical replicates each and are expressed as the mean $\pm \mathrm{SD} . * * *, P<0.001$. 

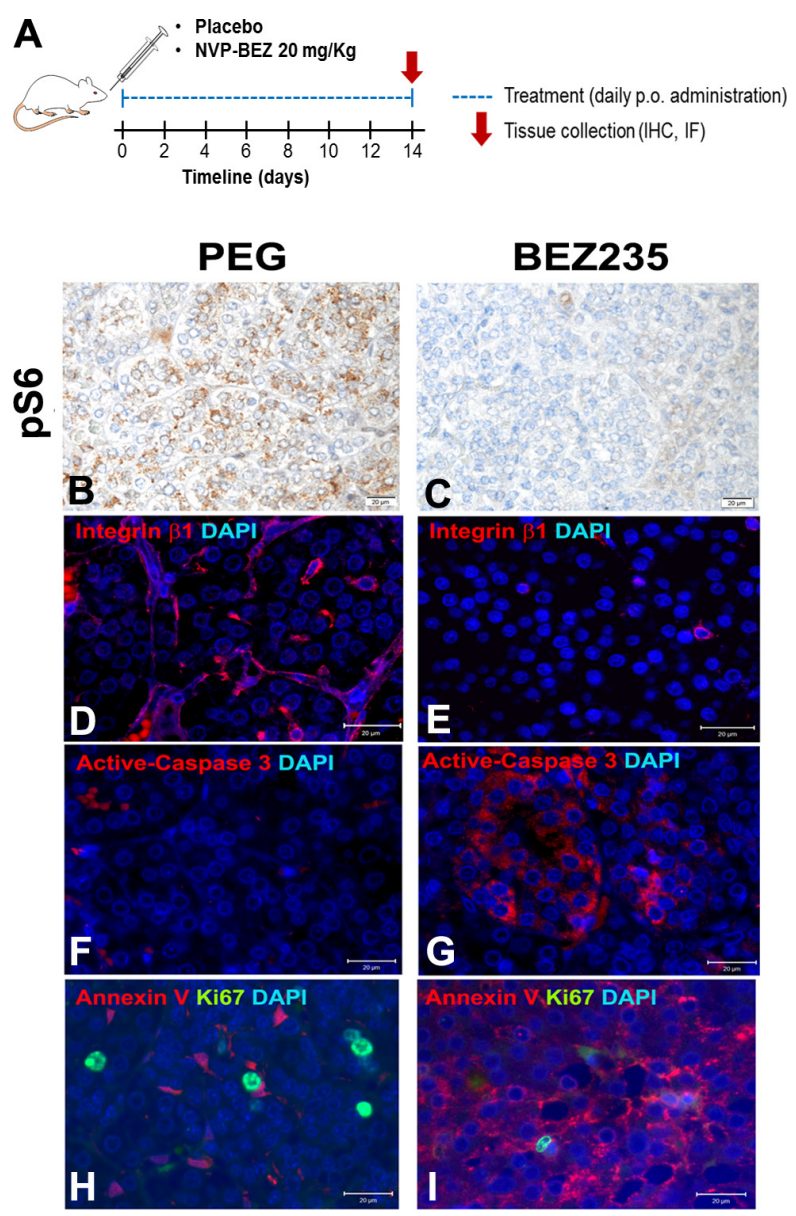

Figure 7: Ex vivo analysis of rat PCCs following placebo or NVP-BEZ235 treatment. MENX-affected rats $(n=4)$ were treated with a dual PI3K/mTOR inhibitor, NVP-BEZ235, or with PEG vehicle $(n=4)$ by oral gavage for 2 weeks then adrenal glands were collected. A-I. IF or IHC on tissues collected from the rats was performed using specific antibodies raised against P-S6, integrin $\beta 1$, Ki67, Annexin V or active-caspase3. For IHC, haematoxylin was used as counterstaining, while for IF, cell nuclei were counterstained with DAPI. Original magnification: $\times 400$. Scale bars: $20 \mu \mathrm{M}$.

through autocrine- and paracrine-mediated activation of $\mathrm{PI} 3 \mathrm{~K} / \mathrm{AKT} / \mathrm{mTOR}$ signaling cascade and of integrin $\beta 1$ expression. We demonstrated that this knowledge may be exploited for therapeutic purposes in proof-of-principle studies using in vitro and in vivo PCC models.

We previously reported that $B M P 7$ is overexpressed in human PCC [14]. In this study, we demonstrate that the BMP7 protein is highly expressed in $72 \%$ of human tumors and it associates with tumor location (more frequently elevated in PGLs than in PCCs) and tumor size (higher in large PCCs). Of note, tumor size positively correlates with a higher malignancy risk for PCC [6], and, although data are not always consistent, an increased malignancy rate has been reported for PGLs compared with PCCs [6]. In our patient cohort, nine of 11 malignant tumors (82\%) had high BMP7 expression. As BMP7 has already been shown to be a marker of tumor progression and metastases development in breast and esophageal cancers [25,37], it is worth further exploring the potential of BMP7 as a marker of malignant behavior by analyzing additional malignant $\mathrm{PCC}$ cases for its expression.
Our understanding of the contribution of BMP signaling to cancer biology remains limited. Although activation of BMP-mediated pathways inhibits cell growth and induces apoptosis in various cancer cell types, it can also be implicated in increasing metastatic potential and tumor angiogenesis in other tumor types $[25,26,38]$. To date, the contribution of BMP7 signaling to PCC pathogenesis has not been addressed. By manipulating endogenous Bmp 7 levels in PCC cell lines (overexpression and knockdown) and in primary rat tumor cells (knockdown), we could demonstrate that endogenous Bmp 7 overexpression promotes oncogenic features in these cells. Specifically, high Bmp 7 gene expression promoted the proliferation and potently induced the migration and invasion of PC12, MPC, and MTT cells. This situation is reminiscent of what has been reported about activation of BMP2- and BMP4-dependent pathways in other tumor types [39, 40]. Moreover, shRNA-mediated $B m p 7$ gene silencing reduced the viability of rat primary PCC cells, suggesting that in this experimental system Bmp7 sustains 
cell survival. Thus, similar to what has been reported for lung cancer [41], melanoma [42] and, albeit controversial, for breast cancer [25], BMP7 exerts a tumor-promoting action in PCC.

Because BMP7 strongly increases the motility and invasion of PCC cells, we investigated the molecular mechanisms that might mediate these effects. We focused on integrin $\beta 1$ : a major cell adhesion molecule in mammalian cells, extensively associated with the motility and invasion of tumor cells, and expressed in all PCC cell lines. No data were available up to now on integrin $\beta 1$ involvement in PCC. We observed that both ectopic Bmp7 overexpression and treatment with rhBMP7 associate with enhanced integrin $\beta 1$ expression in PC12 cells, whereas selective blockade of BMP signaling by DMH1 causes a drastic reduction in integrin $\beta 1$ expression in MTT cells. Knockdown of Itgb1 (integrin $\beta 1$ ) suppresses BMP7mediated increase in proliferation, migration and invasion of PC12 cells. These findings provide experimental evidence to support the functional link between the BMP pathway and integrin $\beta 1$. Moreover, analysis of human primary PCCs revealed for the first time that integrin $\beta 1$ is highly expressed in these tumors and its amount tends to correlate with that of BMP7. In breast cancer cells, it has been reported that BMP7 inhibits TGFbeta-induced invasion via inhibition of integrin $\beta 3$ [43], again attesting to the cell-type dependent effect of BMP7 signaling. In conclusion, we identified integrin $\beta 1$ as a downstream target of BMP-dependent signaling in PCC and as a tumor progression driver.

Human primary PCCs are characterized by the hyperactivation of the PI3K/AKT pathway $[1,44]$. Here we report that over half of PCCs are characterized by high BMP7 expression, and that active BMP-dependent pathways increase P-AKT levels in PCC cells. Thus, it is tempting to speculate that the PI3K pathway activation observed in PCCs might be in part due to BMP7 expression upregulation and the triggering of a cell autonomous stimulatory pathway. Mechanistically, we postulate that BMP7 signaling activates the PI3K/AKT/mTOR pathway, which in turn leads to the up-regulation of integrin $\beta 1$. Indeed, inhibiting AKT or PI3K/ mTOR activities in the context of active BMP7-mediated pathways reduced integrin $\beta 1$ expression in PCC both in vitro and in vivo. Integrin $\beta 1$ up-regulation by the activated $\mathrm{PI} 3 \mathrm{~K} / \mathrm{AKT}$ pathway has been also documented in other cancers, including breast [32] and prostate carcinomas [45], where it accounts for enhanced cell motility and invasion.

Our data uncover downstream effectors of active BMP signaling that could be the target of novel therapeutic strategies for PCC. To verify this, we investigated whether the inhibition of the PI3K/AKT/ mTOR pathway is effective against PCCs expressing high levels of BMP7. Specifically, we exploited our MENX rat model to study the response of endogenous PCCs to a dual PI3K/mTOR inhibitor (NVP-BEZ235) that is bioavailable and in clinical trials. NVP-BEZ235 displays antitumor effects against PCC cell lines and primary rat PCC cells in vitro $[36,46]$. Here, ex vivo analysis of the rat tumors confirmed that NVP-BEZ235 inhibits $\mathrm{BMP}$ and $\mathrm{PI} 3 \mathrm{~K} / \mathrm{mTOR}$ signaling, reduces integrin $\beta 1$ expression and cell proliferation, and induces cell death. Collectively, these data support our hypothesis that targeting the PI3K signaling cascade holds promise in PCC treatment as a paradigm of tumors with active BMP7-mediated signaling. They also suggest that BMP7 might be a potential predictor of response to such antitumor agents.

To date, everolimus (rapamycin analogue) was evaluated in a few patients with progressive/malignant PCCs, but exhibited low efficacy $[10,11]$. This lack of tumor control could be due to the activation of a feedback loop reactivating AKT signaling upstream of mTOR, a well-documented mechanism of resistance to rapamycin and its analogues in various human cancers [47, 48]. To escape the feedback resistance, compounds able to inhibit both mTOR and the upstream PI3K kinase were generated, including NVP-BEZ235 [49]. Our preclinical in vivo trial provides the rationale for targeting the PI3K pathway in patients with progressive/inoperable PCCs using dual PI3K/mTOR inhibitors instead of single-molecule inhibitors.

While drugs inhibiting the PI3K pathway have reached the clinical trial stage or are already approved for treatment, BMP antagonists are still in preclinical development, but may be available for clinical applications in the future. Among them is DMH1, the most selective small molecule inhibitor of BMP receptor signaling currently available [35]. DMH1 inhibits the intracellular kinase domains of BMPR-I molecules such as ALK1 (activing receptor-like kinase 1), ALK2, ALK3/BMPRIA and ALK6/BMPR-IB, but does not inhibit ALK4 and ALK5, nor other kinases such as AMP-activated kinase, VEGF (vascular endothelial growth factor) receptor type 2 and PDGF (platelet-derived growth factor) receptor $\beta[35,50]$. DMH1 has recently been shown to inhibit breast-to-lung metastases and to reduce primary growth of mammary carcinomas in mice [50], and to suppress the tumor growth of a human lung cancer xenograft model [51]. Our data of an antitumor effect elicited by DMH1 in PCC cells hold great promise for future targeted therapies of these tumors.

In summary, our work identifies BMP7 as a novel pro-oncogenic factor in PCC and provides leads for novel therapeutic approaches against PCCs targeting downstream effectors of BMP7-mediated signaling.

\section{MATERIALS AND METHODS}

\section{Human pheochromocytoma samples}

This study was approved by the Ethics Committees of the Universities of Munich, Tübingen, and Florence; 
informed written consent was obtained from all patients. PCC tissues were snap-frozen after surgery and stored at $-80^{\circ} \mathrm{C}$ until required. Frozen normal adrenals and tumors were also provided by the Imperial College Healthcare NHS Trust Tissue Bank (Project R13041).

Tissue microarrays (TMAs) containing 208 human adrenal tumors (166 PCCs, 42 PGLs) and control tissues were obtained from the ENS@T (European Network for the Study of Adrenal Tumors) and previously described [52]. For each tumor, two different areas (cores) were selected for the arrays.

\section{Rat tissue and plasma samples}

Adrenals of age-matched wild-type and MENXaffected rats were fixed in $4 \%$ buffered formalin and embedded in paraffin. Histological examination confirmed the diagnosis of PCC. Three-micrometer sections were used for IHC or IF. Plasma from age-matched wild-type and MENX-affected rats was obtained at autopsy and stored at $-80^{\circ} \mathrm{C}$. Plasma Bmp7 levels were measured with an ELISAKIT obtained from USCN Life Science Inc. (Wuhan, China).

\section{Cell culture, treatments, and assays}

Mouse PCC cells, MPC 4/30 PRR [53], derived from a heterozygous Nf1-mutant mouse PCC, and its more aggressive derivative MTT [54] cells, were kindly provided by Dr. Karel Pacak (NIH, Bethesda, Maryland, USA) and cultured in DMEM medium (Sigma, Hamburg, Germany) containing 10-ml fetal bovine serum (FBS) and $1 \%(\mathrm{v} / \mathrm{v})$ penicillin/streptomycin at $37^{\circ} \mathrm{C}$ in a $5 \% \mathrm{CO}_{2}$ atmosphere. Rat PC12 cells were purchased from LGC Standards (Wesel, Germany) and cultivated, following manufacturer's instructions. All cells were routinely tested for mycoplasma and found free of contamination. Moreover, they were maintained in culture for maximum 5 passages after thawing. Primary PCC cells from MENX mutant rats were established and cultivated as previously reported [36].

PC12 cells were transfected with plasmid DNA as described [17], or with 200 pmol of scrambled (ON TARGETplus Non-targeting siRNA, Dharmacon, Lafayette, CO, USA) or pooled siRNA against rat Itgbl gene (ON-TARGET plus SMART pool siRNA, Dharmacon) by Amaxa 4D-Nucleofector (Lonza) following the manufacturer's instruction. For infections, MPC, MTT, and primary tumor cells were plated on 96-well plates and were infected with lentiviral vectors expressing either green fluorescence protein (GFP) alone (pGreenPuro \#SI505A-1-SBI, BioCat, Heidelberg, Germany) or GFP and shRNA against BMP7. Virus productions were performed as published [55] and infections slightly adjusted to the described protocol. Two different shBmp7 sequences were originally cloned into a pGreenPuro lentiviral vector: \#1.8: FW
AGGCCTGATTGGACGGCAT; \#2.9: FW 5'-CGGGA GAUGCAGCGGGAAA-3'.

WST-1 colorimetric assay (Roche, Mannheim, Germany) for cell viability was performed $72 \mathrm{~h}$ after infection according to the manufacturer's recommendations.

\section{Protein extraction and western blotting}

Cells were harvested after treatment with rhBMP7 transfection or infection at specific timepoints. Total proteins were extracted from cells or frozen tissues, and western blotting was performed as previously reported [56]. The primary antibodies used are: human anti-BMP7 (R\&D Systems, USA; clone \#164311; dilution 1:1000); rat anti-Bmp7 (\#4693, 1:100), P-Smad1/5/8 (\#9511, 1:50), Smad1 (\#5753; 1:500), AKT (\#9272; 1:500) and P-AKT (\#9271; 1:500) all from Cell Signaling Technology (Danvers MA, USA); integrin $\beta 1$ (Abcam, Cambridge, UK; \#EP1041Y; dilution 1:500); anti-Myc tag (Clontech, St-Germain-en-Laye, France; \#631206; dilution 1:500), $\alpha$-Tubulin (Sigma-Aldrich, Hamburg, Germany; \#T5168; dilution 1:1000). Western blotting experiments from biological replicates showed similar expression data, attesting to the reproducibility of the results.

\section{IHC and IF}

IHC was performed on an automated immunostainer (Ventana Medical Systems, Tucson, AZ) as previously described [57]. The primary antibodies used are: rat antiBMP7 antibody (see above; dilution 1:100), human antiBMP7 (see above; dilution 1:1000), anti-P-S6 antibody (Cell Signaling Technology; \#2211; 1:500). Primary antibodies were diluted in Dako REALTM antibody diluent (Dako, Hamburg, Germany). Haematoxylin was used as counterstaining. Positive controls were included in each batch. TMAs were scored for BMP7 expression using a semi-quantitative method taking into account the staining intensity: - (negative), + (mild), ++ (moderate), and +++ (strong). Slides were scored using a double-blind method by two independent observers; the percentage of discrepancies was below 3\%. We only considered tumors for which both cores could be scored after IHC staining processes (inclusion criteria). Images were recorded using a Hitachi camera HW/C20 installed in a Zeiss Axioplan microscope with Intellicam software (Carl Zeiss MicroImaging, Göttingen, Germany).

For IF, we used primary antibodies against BMP7 (see above), P-Smad1/5/8 (see above), integrin $\beta 1$ (1:200), Ki67 (BD Biosciences, Heidelberg, Germany; \#550609; 1:100), Annexin V (Abcam; ab14196; 1:100) or active-caspase3 (Cell Signaling; \#9664; 1:200). Cell nuclei were counterstained with DAPI. Secondary anti-mouse Alexa Fluor ${ }^{\circledR} 555$ Conjugate (Cell Signaling), secondary anti-rabbit FITC-conjugated antibody (Invitrogen, Darmstadt, Germany) were used as reported [58]. Sections 
were analyzed with a Zeiss Axiovert 200 epifluorescence microscope including Apotome unit (Carl Zeiss).

\section{Migration and invasion assays}

Chemomigration assays were performed using 24-well plates with uncoated polycarbonate membrane inserts (BD BioCoat ${ }^{\mathrm{TM}}, \mathrm{BD}$, Heidelberg, Germany). Cells were transfected with Myc-BMP7 or empty vector, and trypsinized and collected $24 \mathrm{~h}$ later in a medium containing $0.02 \% \mathrm{FBS}$ and $0.1 \%$ horse serum (HS). A total of 50000 cells (PC12) or 100000 cells (MPC/MTT) were added onto the insert. The lower well was filled with a medium complemented with 2.5\% FBS and 15\% HS. Migrated cells were fixed $24 \mathrm{~h}$ later in $100 \%$ methanol and stained with $1.5 \%(\mathrm{w} / \mathrm{v})$ toluidine blue in water. MPC and MTT cells were infected for $B m p 7$ knockdown and the same procedure as above was employed after $72 \mathrm{~h}$. Invasion assays were performed with matrigel-coated polycarbonate membrane inserts (BD BioCoat ${ }^{\mathrm{TM}}, \mathrm{BD}$ ) according to the manufacturer's recommendations. We plated 75000 cells (PC12) or 150000 cells (MPC/MTT) for these assays.

\section{Quantitative TaqMan RT-PCR}

RNA was extracted using RNeasy Mini Kit (Qiagen, Hilden, Germany) following the manufacturer's instructions. Quantitative RT-PCR was performed using TaqMan inventoried primers and probes (Applied Biosystem, CA, USA) for the indicated genes, following previously reported protocols [14].

\section{RT-PCR analysis of Bmp receptor genes}

Semiquantitative RT-PCR was performed for Bmp receptor transcripts using RNA extracted from microdissected adrenomedullary cells of the tissue samples or MPC, MTT, PC12, and primary cells of rat PCCs. Primers used for semi-quantitative analysis are described in Supplementary Table S1. Conditions for the RT-PCR reaction were as previously reported [14].

\section{In vivo treatment}

This study was approved by the ethics committee on animal research of the government of Upper Bavaria, Germany. MENX-affected rats were maintained as previously reported [12] in agreement with the procedures approved by the Helmholtz Zentrum München, by the Technische Universität München, and by the local government authorities.

NVP-BEZ235 was kindly supplied by Novartis Pharma. In preliminary experiments, various doses of NVPBEZ235 were tested in MENX rats, as reported [58], and the dose of $20 \mathrm{mg} / \mathrm{Kg}$ was selected. MENX-affected rats at 7-8 months of age (with adrenal tumors but still in good general health) were treated for 14 days with NVP-BEZ235 $(20 \mathrm{mg}$ / $\mathrm{kg}$ ) or placebo (PEG) administered daily per oral gavage. At the end of the treatment, adrenal glands were collected for IHC and IF of relevant markers.

\section{Statistical analyzes}

Study endpoints from the in vitro experiments, including cell proliferation, migration, and invasion, as well as primary cell viability are summarized using bar graphs with means \pm SD. A paired two-tailed Student's $t$ test was used to detect significance between two series of data, and $P<0.05$ was considered significant. For TMA results, the staining results were compared with the clinicopathological features and correlations were assessed using Fisher's exact test.

\section{ACKNOWLEDGMENTS}

The authors thank E. Samson, E. Pulz, and D. Mörzl for excellent technical assistance, and Profs. A.S. Tischler and K. Pacak for kindly providing MPC and MTT cells. We acknowledge the Imperial College Healthcare NHS Trust Tissue Bank for providing samples for our study.

\section{CONFLICTS OF INTEREST}

The authors declare no conflict of interest.

\section{GRANT SUPPORT}

This work was supported by grant \# 2012.037.1 from the Wilhelm Sander Stiftung (to N.S.P. and F.B.) as well as grant \#110874 from the Deutsche Krebshilfe (to N.S.P.). The research leading to these results has also received funding from the Seventh Framework Programme (FP7/2007-2013) under grant agreement $n^{\circ} 259735$.

\section{REFERENCES}

1. Favier J, Amar L, Gimenez-Roqueplo AP. Paraganglioma and phaeochromocytoma: from genetics to personalized medicine. Nat Rev Endocrinol. 2015; 11:101-111.

2. Castro-Vega LJ, Letouzé E, Burnichon N, Buffet A, Disderot PH, Khalifa E, Loriot C, Elarouci N, Morin A, Menara M, Lepoutre-Lussey C, Badoual C, Sibony M, et al. Multi-omics analysis defines core genomic alterations in pheochromocytomas and paragangliomas. Nat Commun. 2015; 6:6044.

3. Fishbein L, Khare S, Wubbenhorst B, DeSloover D, D'Andrea K, Merrill S, Cho NW, Greenberg RA, Else T, Montone K, LiVolsi V, Fraker D, Daber R, et al. Wholeexome sequencing identifies somatic ATRX mutations in pheochromocytomas and paragangliomas. Nat Commun. 2015; 6:6140. 
4. Eisenhofer G, Huynh TT, Pacak K, Brouwers FM, Walther MM, Linehan WM, Munson PJ, Mannelli M, Goldstein DS, Elkahloun AG. Distinct gene expression profiles in norepinephrine- and epinephrine-producing hereditary and sporadic pheochromocytomas: activation of hypoxia-driven angiogenic pathways in von Hippel-Lindau syndrome. Endocr Relat Cancer. 2004; 11:897-911.

5. Lopez-Jimenez E, Gomez-Lopez G, Leandro-Garcia LJ, Munoz I, Schiavi F, Montero-Conde C, de Cubas AA, Ramires R, Landa I, Leskelä S, Maliszewska A, Inglada-Pérez L, de la Vega L, et al. Research resource: Transcriptional profiling reveals different pseudohypoxic signatures in SDHB and VHL-related pheochromocytomas. Mol Endocrinol. 2010; 24:2382-2391.

6. Ayala-Ramirez M, Feng L, Johnson MM, Ejaz S, Habra MA, Rich T, Busaidy N, Cote GJ, Perrier N, Phan A, Patel S, Waguespack S, Jimenez C. Clinical risk factors for malignancy and overall survival in patients with pheochromocytomas and sympathetic paragangliomas: primary tumor size and primary tumor location as prognostic indicators. J Clin Endocrinol Metab. 2011; 96:717-725.

7. Eisenhofer G, Bornstein SR, Brouwers FM, Cheung NK, Dahia PL, de Krijger RR, Giordano TJ, Greene LA, Goldstein DS, Lehnert H, Manger WM, Maris JM, Neumann HP, et al. Malignant pheochromocytoma: current status and initiatives for future progress. Endocr Relat Cancer. 2004; 11:423-436.

8. Loh KC, Fitzgerald PA, Matthay KK, Yeo PP, Price DC. The treatment of malignant pheochromocytoma with iodine-131 metaiodobenzylguanidine (131I-MIBG): a comprehensive review of 116 reported patients. J Endocrinol Inv. 1997; 20:648-658.

9. Joshua AM, Ezzat S, Asa SL, Evans A, Broom R, Freeman M, Know JJ. Rationale and evidence for sunitinib in the treatment of malignant paraganglioma/pheochromocytoma. J Clin Endocrinol Metab. 2009; 94:5-9.

10. Druce MR, Kaltsas GA, Fraenkel M, Gross DJ, Grossman AB. Novel and evolving therapies in the treatment of malignant phaeochromocytoma: experience with the mTOR inhibitor everolimus (RAD001). Horm Metab Res. 2009; 41:697-702.

11. Oh DY, Kim TW, Park YS, Shin SJ, Shin SH, Song EK, Lee HJ, Lee KW, Bang YJ. Phase 2 study of everolimus monotherapy in patients with nonfunctioning neuroendocrine tumors or pheochromocytomas/paragangliomas. Cancer. 2012; 118:6162-70.

12. Fritz A, Walch A, Piotrowska K, Rosemann M, Schaffer E, Weber K, Timper A, Wildner G, Graw J, Höfler H, Atkinson MJ. Recessive transmission of a multiple endocrine neoplasia syndrome in the rat. Cancer Res. 2002; 62:3048-3051.

13. Shyla A, Holzlwimmer G, Calzada-Wack J, Bink K, Tischenko O, Guilly MN, Chevillard S, Samson E, Graw J, Atkinson MJ, Pellegata NS. Allelic loss of chromosomes 8 and 19 in MENX-associated rat pheochromocytoma. Int $\mathrm{J}$ Cancer. 2010; 126:2362-2372.

14. Molatore S, Liyanarachchi S, Irmler $\mathrm{M}$, Perren $\mathrm{A}$, Mannelli M, Ercolino T, Beuschlein F, Jarzab B, Wloch J, Ziaja J, Zoubaa S, Neff F, Beckers J, et al. Pheochromocytoma in rats with multiple endocrine neoplasia (MENX) shares gene expression patterns with human pheochromocytoma. Proc Natl Acad Sci U S A. 2010; 107:18493-18498.

15. Miederer $\mathrm{M}$, Molatore $\mathrm{S}$, Marinoni I, Perren A, Spitzweg C, Reder S, Wester H-J, Buck AK, Schwaiger M, Pellegata NS. Functional Imaging of Pheochromocytoma with 68Ga-DOTATOC and 11C-HED in a Genetically Defined Rat Model of Multiple Endocrine Neoplasia. Int J Mol Imaging. 2011; :175352.

16. Gaertner FC, Wiedemann T, Yousefi BH, Lee M, Repokis I, Higuchi T, Nekolla SG, Yu M, Robinson S, Schwaiger M, Pellegata NS. Preclinical evaluation of 18F-LMI1195 for in vivo imaging of pheochromocytoma in the MENX tumor model. J Nucl Med. 2013; 54:2111-2117.

17. Pellegata NS, Quintanilla-Martinez L, Siggelkow H, Samson E, Bink K, Höfler H, Fend F, Graw J, Atkinson MJ. Germline mutations in $\mathrm{p} 27 \mathrm{Kip} 1$ cause a multiple endocrine neoplasia syndrome in rats and man. Proc Natl Acad Sci USA. 2006; 103:15558-63.

18. Chen D, Zhao M, Harris SE, Mi Z. Signal transduction and biological functions of bone morphogenetic proteins. Front Biosci. 2004; 9:349-358.

19. Wang RN, Green J, Wang Z, Deng Y, Qiao M, Peabody M, Zhang Q, Ye J, Yan Z, Denduluri S, Idowu O, Li M, Shen C, et al. Bone Morphogenetic Protein (BMP) signaling in development and human diseases. Genes Dis. 2014; 1:87-105.

20. Thawani JP, Wang AC, Than KD, Lin CY, La Marca F, Park P. Bone morphogenetic proteins and cancer: review of the literature. Neurosurgery. 2010; 66:233-246.

21. Kishigami S, Mishina Y. BMP signaling and early embryonic patterning. Cytokine Growth Factor Rev. 2005; $16: 265-278$.

22. Heldin $\mathrm{CH}$, Miyazono K, ten Dijke P. TGF-beta signalling from cell membrane to nucleus through SMAD proteins. Nature. 1997; 390:465-471.

23. von Bubnoff A, Cho KW. Intracellular BMP signaling regulation in vertebrates: pathway or network? Dev Biol. 2001; 239:1-14.

24. Blanco Calvo M, Bolós Fernández V, Medina Villaamil V, Aparicio Gallego G, Díaz Prado S, Grande Pulido E. Biology of BMP signalling and cancer. Clin Transl Oncol. 2009; 11:126-37.

25. Alarmo EL, Korhonen $\mathrm{T}$, Kuukasjarvi $\mathrm{T}$, Huhtala $\mathrm{H}$, Holli K, Kallioniemi A. Bone morphogenetic protein 7 expression associates with bone metastasis in breast carcinomas. Ann Oncol. 2008; 19:308-314. 
26. Gespach C, Grijelmo C, Rodrigue C, Svrcek M, Bruyneel E, Hendrix A, de Wever O, Gespach C. Proinvasive activity of BMP-7 through SMAD4/src-independent and ERK/Rac JNK-dependent signaling pathways in colon cancer cells. Cell Signal. 2007; 19:1722-1732.

27. Aoki M, Ishigami S, Uenosono Y, Arigami T, Uchikado Y, Kita Y, Kurahara H, Matsumoto M, Ueno S, Natsugoe S. Expression of BMP-7 in human gastric cancer and its clinical significance. Br J Cancer. 2011; 104:714-718.

28. Miyazaki H, Watabe T, Kitamura T, Miyazono K. BMP signals inhibit proliferation and in vivo tumor growth of androgen-insensitive prostate carcinoma cells. Oncogene. 2004; 23:9326-9335.

29. Greene LA, Tischler AS. Establishment of a noradrenergic clonal line of rat adrenal pheochromocytoma cells which respond to nerve growth factor. Proc Natl Acad Sci U S A. 1976; 73:2424-2428.

30. Goto J, Otsuka F, Yamashita M, Suzuki J, Otani H, Takahashi H, Miyoshi T, Mimura Y, Ogura T, Makino H. Enhancement of aldosterone-induced catecholamine production by bone morphogenetic protein- 4 through activating Rho and SAPK/JNK pathway in adrenomedullar cells. Am J Physiol Endocrinol Metab. 2009; 296:E904-916.

31. Hynes RO. Integrins: bidirectional, allosteric signaling machines. Cell. 2002; 110:673-687.

32. Adelsman MA, McCarthy JB, Shimizu Y. Stimulation of beta1-integrin function by epidermal growth factor and heregulin-beta has distinct requirements for erbB2 but a similar dependence on phosphoinositide 3-OH kinase. Mol Biol Cell. 1999; 10:2861-2878.

33. Fong YC, Li TM, Wu CM, Hsu SF, Kao ST, Chen RJ, Lin CC, Liu SC, Wu CL, Tang CH. BMP-2 increases migration of human chondrosarcoma cells via PI3K/Akt pathway. J Cell Physiol. 2008; 217:846-855.

34. Panupinthu N, Yu S, Zhang D, Zhang F, Gagea M, Lu Y, Grandis JR, Dunn SE, Lee HY, Mills GB. Self-reinforcing loop of amphiregulin and Y-box binding protein-1 contributes to poor outcomes in ovarian cancer. Oncogene. 2014; 33:2846-2856.

35. Hao J, Ho JN, Lewis JA, Karim KA, Daniels RN, Gentry PR, Hopkins CR, Lindsley CW, Hong CC. In vivo structure-activity relationship study of dorsomorphin analogues identifies selective VEGF and BMP inhibitors. ACS Chem Biol. 2010; 5:245-53.

36. Lee M, Waser B, Reubi JC, Pellegata NS. Secretin receptor promotes the proliferation of endocrine tumor cells via the PI3K/AKT pathway. Mol Endocrinol. 2012; 26:1394-1405.

37. Xu G, Tang S, Yang J, Chen K, Kang J, Zhao G, Feng F, Yang X, Zhao L, Lu Q, Sun L, Hong L, Gong T, et al. BMP7 expression in esophageal squamous cell carcinoma and its potential role in modulating metastasis. Dig Dis Sci. 2013; 58:1871-1879.

38. Buijs JT, Henriquez NV, van Overveld PG, van der Horst G, ten Dijke P, van der Pluijm G. TGF-beta and
BMP7 interactions in tumour progression and bone metastasis. Clin Exp Metastasis. 2007; 24:609-617.

39. Jin H, Pi J, Huang X, Huang F, Shao W, Li S, Chen Y, Cai J. BMP2 promotes migration and invasion of breast cancer cells via cytoskeletal reorganization and adhesion decrease: an AFM investigation. Appl Microbiol Biotechnol. 2012; 93:1715-1723.

40. Guo D, Huang J, Gong J. Bone morphogenetic protein 4 (BMP4) is required for migration and invasion of breast cancer. Mol Cell Biochem. 2012; 363:179-90.

41. Liu Y, Chen J, Yang Y, Zhang L, Jiang WG. Molecular impact of bone morphogenetic protein 7, on lung cancer cells and its clinical significance. Int J Mol Med. 2012; 29:1016-1024.

42. Rothhammer T, Poser I, Soncin F, Bataille F, Moser M, Bosserhoff AK. Bone morphogenic proteins are overexpressed in malignant melanoma and promote cell invasion and migration. Cancer Res. 2005; 65:448-456.

43. Naber HP, Wiercinska E, Pardali E, van Laar T, Nirmala E, Sundqvist A, van Dam H, van der Horst $G$, van der Pluijm G, Heckmann B, Danen EH, Ten Dijke P. BMP-7 inhibits TGF- $\beta$-induced invasion of breast cancer cells through inhibition of integrin $\beta(3)$ expression. Cell Oncol. 2012; 35:19-28.

44. Fassnacht M, Weismann D, Ebert S, Adam P, Zink M, Beuschlein F, Hahner S, Allolio B. AKT is highly phosphorylated in pheochromocytomas but not in benign adrenocortical tumors. J Clin Endocrinol Metab. 2005; 90:4366-4370.

45. Tsaur I, Makarevic J, Juengel E, Gasser M, WaagaGasser AM, Kurosch M, Reiter M, Wedel S, Bartsch G, Haferkamp A, Wiesner C, Blaheta RA. Resistance to the mTOR-inhibitor RAD001 elevates integrin alpha2- and beta1-triggered motility, migration and invasion of prostate cancer cells. Br J Cancer. 2012; 107:847-855.

46. Nolting S, Garcia E, Alusi G, Giubellino A, Pacak K, Korbonits M, Grossman AB. Combined blockade of signalling pathways shows marked anti-tumour potential in phaeochromocytoma cell lines. J Mol Endocrinol. 2012; 49:79-96.

47. Hosoi H, Dilling MB, Liu LN, Danks MK, Shikata T, Sekulic A, Abraham RT, Lawrence JC Jr, Houghton PJ. Studies on the mechanism of resistance to rapamycin in human cancer cells. Mol Pharmacol. 1998; 54:815-824.

48. Tan J, Yu Q. Molecular mechanisms of tumor resistance to PI3K-mTOR-targeted therapy. Chin J Cancer. 2013; 32:376-379.

49. Maira SM, Stauffer F, Brueggen J, Furet P, Schnell C, Fritsch C, Brachmann S, Chène $\mathrm{P}$, De Pover A, Schoemaker K, Fabbro D, Gabriel D, Simonen M, et al. Identification and characterization of NVP-BEZ235, a new orally available dual phosphatidylinositol 3-kinase/mammalian target of rapamycin inhibitor with potent in vivo antitumor activity. Mol Cancer Ther. 2008; 7:1851-1863. 
50. Owens P, Pickup MW, Novitskiy SV, Giltnane JM, Gorska AE, Hopkins CR, Hong CC, Moses HL. Inhibition of BMP signaling suppresses metastasis in mammary cancer. Oncogene. 2015; 34:2437-49.

51. Hao J, Lee R, Chang A, Fan J, Labib C, Parsa C, Orlando R, Andresen B, Huang Y. DMH1, a small molecule inhibitor of BMP type i receptors, suppresses growth and invasion of lung cancer. PLoS One. 2014; 9:e90748.

52. Oudijk L, Neuhofer CM, Lichtenauer UD, Papathomas TG, Korpershoek E, Stoop H, Oosterhuis JW, Smid M, Restuccia DF, Robledo M, de Cubas AA, Mannelli M, Gimenez-Roqueplo AP, et al. Immunohistochemical expression of stem cell markers in pheochromocytomas/ paragangliomas is associated with SDHx mutations. Eur J Endocrinol. 2015; 173:43-52.

53. Powers JF, Evinger MJ, Tsokas P, Bedri S, Alroy J, Shahsavari M, Tischler AS. Pheochromocytoma cell lines from heterozygous neurofibromatosis knockout mice. Cell Tissue Res. 2000; 302:309-320.

54. Martiniova L, Lai EW, Elkahloun AG, Abu-Asab M, Wickremasinghe A, Solis DC, Perera SM, Huynh TT, Lubensky IA, Tischler AS, Kvetnansky R, Alesci S,
Morris JC, et al. Characterization of an animal model of aggressive metastatic pheochromocytoma linked to a specific gene signature. Clin Exp Metastasis. 2009; 26:239-250.

55. Höfig I, Atkinson MJ, Mall S, Krackhardt AM, Thirion C, Anastasov N. Poloxamer synperonic F108 improves cellular transduction with lentiviral vectors. J Gene Med. 2012; 14:549-560.

56. Molatore S, Kiermaier E, Jung CB, Pulz E, Höfler H, Atkinson MJ, Pellegata NS. Characterization of a naturallyoccurring p27 mutation predisposing to multiple endocrine tumors. Mol Cancer. 2010; 9:116.

57. Lee M, Lupp A, Mendoza N, Martin N, Beschorner R, Honegger J, Schlegel J, Shively T, Pulz E, Schulz S, Roncaroli F, Pellegata NS. Somatostatin receptor 3 is a putative target for the medical treatment of gonadotroph adenomas of the pituitary. Endocr Relat Cancer. 2014; 22:111-9.

58. Lee M, Wiedemann T, Gross C, Roncaroli F, Braren R, Pellegata NS. Targeting PI3K/mTOR signaling displays potent antitumor efficacy against nonfunctioning pituitary adenomas. Clinical Cancer Research. 2015; Apr. 2; [Epub ahead of print. 